\title{
Perlindungan Hukum Terhadap Nasabah Pengguna Kartu Automatic Teller Machine
}

\author{
Muhammad Akbar Fhad Syahril \\ Sekolah Tinggi Ilmu Hukum Amsir Parepare \\ Email : akbar9.a9@gmail.com
}

\begin{abstract}
The community has now been introduced to various kinds of conveniences. The services provided by the banking sector certainly also play an important role in it, apart from providing convenience, it turns out that this also has weaknesses that will indirectly harm the customers of service users and banks that provide services. This study aims to determine and analyze how the responsibility and legal protection of customers in Automatic Teller Machine transactions and legal efforts that can be taken by customers who use Automatic Teller Machine cards in obtaining their rights in the event of a loss in the use of the Automatic Teller Machine. This research method uses juridical normative research, which is research conducted with an approach to legal norms or substances, legal principles, legal arguments and legal comparisons, using a conceptual approach which is a type of approach in legal research that provides an analytical perspective on solving problems in legal research, which is seen from the aspects and legal concepts behind it, can even be seen from the values contained in the norming of a regulation related to the concepts used. The results showed that the bank was fully responsible for errors that resulted in losses to customers. And the legal remedy that can be taken is to file a written complaint that is submitted to the bank
\end{abstract}

Keyword: Legal Protection, Responsibility and Banking Law.

\begin{abstract}
Abstrak
Masyarakat kini sudah diperkenalkan dengan berbagai macam kemudahan. Jasa yang diberikan oleh pihak perbankan tentunya juga sangat berperan penting didalamnya, selain memberikan kemudahan ternyata hal tersebut juga mempunyai kelemahan-kelemahan yang secara tidak langsung akan merugikan nasabah pengguna jasa dan perbankan yang memberikan pelayanan jasa. Penelitian ini bertujuan untuk mengetahui dan menganalisis bagaimana tanggung jawab dan perlindungan hukum terhadap nasabah pada transaksi Automatic Teller Machine dan upaya hukum yang dapat dilakukan oleh nasabah pengguna kartu Automatic Teller Machine dalam memperoleh hak-haknya apabila terjadi kerugian dalam penggunaan Automatic Teller Machine. Metode penelitian ini menggunakan penelitian normatif yuridis, yakni penelitian yang dilakukan dengan pendekatan pada norma atau substansi hukum, asas hukum, dalil-dalil hukum dan perbandingan hukum, dengan menggunakan pendekatan konseptual yang merupakan suatu jenis pendekatan di dalam penelitian hukum yang memberi sudut pandang analisa terhadap penyelesaian permasalahan dalam penelitian hukum, yang dilihat dari aspek dan konsep-konsep hukum yang melatarbelakanginya, bahkan bisa juga dilihat dari nilai-nilai yang terkandung dalam penormaan sebuah peraturan yang sekaitan dengan konsep-konsep yang digunakan. Hasil penelitian menunjukkan bahwa bank bertanggung jawab penuh terhadap kesalahan yang mengakibatkan kerugian terhadap nasabah. Dan upaya hukum yang dapat dilakukan yakni melakukan pengaduan yang dilakukan secara tertulis yang disampaikan kepada bank.

Kata Kunci: Perlindungan Hukum, Tanggung Jawab dan, Hukum Perbankan.
\end{abstract}




\section{PENDAHULUAN}

Pada dasarnya bank dalam melaksanaan pemberian kredit, tentunya menerapkan prinsip kehati-hatian. sebagaimana di dalam Pasal 6 Peraturan Bank Indonesia Nomor 18/21/PBI/2016 tentang perubahan atas Peraturan Bank Indonesia no. 9/14/PIB/2007 tentang sistem informasi debitur, yang pada prakteknya adalah dengan pengecekan nasabah melalui Bank Indonesia checking dan penyampaian laporan debitur oleh pelapor dalam hal ini adalah bank yang pernah memberikan fasilitas pembiayaan kredit, kepada Bank Indonesia secara akurat dan terkini untuk posisi akhir bulan.(Said, 2017).

Peranan dan fungsi perbankan secara langsung maupun tidak langsung yaitu dengan memberikan jasa juga mekanisme pembayaran yang mudah cepat dan aman. Bank saat ini memanfaatkan kemajuan teknologi sejalan dengan perkembangan zaman, dimana berusaha memberikan berbagai fasilitas yang semakin modern dalam melayani nasabah, diantaranya dengan menyediakan Automated Teller Machine. Pelayanan khusus yang terdapat dalam perbankan, yaitu layanan transfer dana menggunakan Kartu Automatic Teller Machine atau kartu debit dan secara meluas keberadaannya sangat amat membantu dalam proses melakukan transaski sehari-hari.

Automatic Teller Machine menggantikan fungsi dari uang sebagai alat untuk melakukan pembayaran, penggunaan kartu Automatic Teller Machine dirasakan lebih aman dan praktis untuk segala keperluan. Jika tadinya nasabah dilayani oleh petugas bank di kantor bank yang bersangkutan apabila hendak bertransaksi, dengan kartu Automatic Teller Machine nasabah tetap dapat mengendalikan kegiatan keuangan rutin tersebut tanpa harus pergi ke kantor yang bersangkutan. Pemindahan ini berlaku terhadap tabungan milik nasabah.

Pemindahan uang melalui bank merupakan pengiriman uang atas permintaan pihak pengirim dengan menggunakan bank sebagai peraturan agar uang tersebut dibayar kepada pihak yang dituju (Beneficiary, Transfere).(Fuady, 2001) Beberapa permasalahan yang krmudian timbul akibat adanya layanan perbankan digital seperti kejahatan Cyber Crime yang kini semakin marak dan semakintingginya perkembangan teknik penyalahgunaan dataoleh pihak yang tidak bertanggungjawab. Cyber Crime sudah menjadi kejahatan nomor satu dalam dunia perbankan, terlebih lagi di era digital seperti sekarang.(Tarigan \& Paulus, 2019).

Penelitian ini diambil dari beberapa contoh penelitian terdahulu sebagai panduan ataupun contoh untuk penelitian yang dilakukan saat ini. Diambil berupa jurnal-jurnal mengenai Perlindungan Hukum Nasabah Perbankan Dalam Transaksi Elektronik pada tulisan 
tersebut membahas mengenai perlindungan hukum terhadap nasabah perbankan dalam praktik transaksi elektronikberhubungan dengan tanggung jawab bank atas keabsahan informasi nasabah adalah dengan mengendalikan risiko yang sudah diatur dalam peraturan bank Indonesia serta Undang-Undang Informasi Transaksi Elektronik, selain itu mencegah agar tidak terjadinya kejahatan dalam elektronik dengan mengupayakan konsumen agar selalu update terhadap pembaharuan data nasabah.

Kemudian jurnal mengenai Fungsi lembaga penjamin simpanan dalam rangka perlindungan hukum bagi nasabah perbankan di indonesia, pada penelitian tersebut membahas mengenai Perlindungan hukum terhadap nasabah penyimpan dana dalam sistem perbankan di Indonesia dilakukan secara implisit dan secara eksplisit. Perlindungan secara implisit melalui pengawasan dan pembinaan yang dilakukan oleh Bank Indonesia untuk menghindarkan kebangkrutan bank. Melalui peraturan perundang-undangan yakni UU Perbankan dan UU Perlindungan Konsumen, memelihara tingkat kesehatan bank, melakukan usaha sesuai dengan prinsip kehati-hatian, cara pemberian kredit yang tidak merugikan bank dan kepentingan nasabah dan menyediakan informasi risiko pada nasabah. Perlindungan secara eksplisit melalui pembentukan suatu lembaga yang menjamin simpanan masyarakat yakni Lembaga Penjamin Simpanan (LPS) sehingga apabila bank mengalami kegagalan, lembaga tersebut yang akan membayar dana masyarakat yang disimpan pada bank yang gagal tersebut.

Keluhan-keluhan pemegang kartu Automatic Teller Machine menarik untuk secara khusus dianalisis. Tidak hanya pada kecenderungan ke depan bahwa semakin banyak transaksi menggunakan Automatic Teller Machine, tapi juga dengan adanya ketergantungan bisnis perbankan pada kehadiran teknologi dan informasi. Secara umum keluhan nasabah dalam permasalahan penggunaan Automatic Teller Machine tersebut dapat digolongkan menjadi dua jenis keluhan finansial yang umumnya yang bersifat kasuistik dan juga keluhan Non finansial yang sifatnya sistematik.

Namun disisi lain nasabah sebagai pengguna layanan jasa perbankan, tentunya sering berada pada posisi kurang diuntungkan, bilamana terjadi perselisihan antara bank dengan nasabahnya. Pihak nasabah sebagai konsumen berada pada posisi yang lemah ketika terjadi gangguan dalam bertransaksi, sehingga konsumen sering dirugikan. Dengan adanya pihak yang dirugikan, tentunya karena terjadi kesalahan dari pihak lainnya, kecuali dalam hal terjadinya Force Majeur. Perlindungan konsumen sendiri dipandang sangatlah penting baik secara materil maupun secara formal. Mengingat semakin pesat perkembangan ilmu pengetahuan dan teknologi, yang juga merupakan penggerak bagi produktivitas dan efisiensi produsen atas 
barang dan jasa yang dihasilkannya dalam rangka mengejar dan mencapai kedua hal tersebut, pada akhirnya baik itu secara langsung maupun tidak langsung, konsumenlah yang akan merasakan dampaknya.

Pada Peraturan Bank Indonesia Tahun 2005, menegaskan bahwa Bank wajib menetapkan kebijakan atau prosedur tertulis tentang penerimaan pengaduan, penanganan dan penyelesaian pengaduan serta pemantauan penanganan dan penyelesaian pengaduan. Hal tersebut dirasa penting untuk dilakukan, demi menjaga keamanan, kenyamanan dan kepastian nasabah untuk bertransaksi, sehingga diharapkan akan tercipta keadilan masyarakat yang di berikan oleh institusi Perbankan. Masyarakat kini sudah diperkenalkan dengan berbagai macam kemudahan. Jasa yang diberikan oleh pihak perbankan tentunya juga sangat berperan penting didalamnya, selain memberikan kemudahan ternyata hal tersebut juga mempunyai kelemahan-kelemahan yang secara tidak langsung akan merugikan nasabah pengguna jasa dan perbankan yang memberikan pelayanan jasa. Penelitian ini bertujuan untuk mengetahui dan menganalisis bagaimana tanggung jawab dan perlindungan hukum terhadap nasabah pada transaksi Automatic Teller Machine dan upaya hukum yang dapat dilakukan oleh nasabah pengguna kartu Automatic Teller Machine dalam memperoleh hak-haknya apabila terjadi kerugian dalam penggunaan Automatic Teller Machine.

\section{METODE PENELITIAN}

Metode penelitian ini menggunakan penelitian normatif yuridis, yakni penelitian yang dilakukan dengan pendekatan pada norma atau substansi hukum, asas hukum, dalil-dalil hukum dan perbandingan hukum. Pendekatan yang digunakan yakni Pendekatan konseptual, yang merupakan suatu jenis pendekatan di dalam penelitian hukum yang memberi sudut pandang analisa terhadap penyelesaian permasalahan dalam penelitian hukum, yang dilihat dari aspek dan konsep-konsep hukum yang melatarbelakanginya, bahkan bisa juga dilihat dari nilai-nilai yang terkandung dalam penormaan sebuah peraturan yang sekaitan dengan konsepkonsep yang digunakan. Penelitian ini bersifat deskriptif analitis yaitu menggambarkan, menganalisis, menyimpulkan masalah-masalah yang menjadi objek penelitian.

\section{PEMBAHASAN}

\section{Kedudukan Nasabah Dalam Hukum Perbankan}

Undang-undang Perbankan dan Undang-undang Perlindungan Konsumen dalam hal ini dapat dikatakan Lex Generalis, dimana diberikannya perlindungan kepada nasabah, selaku konsumen dari pengguna jasa perbankan. Pada Undang-undang No 8 Tahun 1999 tentang Perlindungan Konsumen Pasal 4 disebutkan mengenai hak yang dimiliki oleh konsumen 
sebagai pengguna produk atau jasa tertentu. Hak-hak tersebut meliputi : (a) Hak atas keamanan dan keselamatan; (b) Hak untuk memperoleh informasi; (c) Hak untuk memilih; (d) Hak untuk didengar; (e) Hak untuk memperoleh kebutuhan hidup; (f) Hak untuk memperoleh ganti rugi; (g) Hak untuk memperoleh pendidikan konsumen; (h) Hak memperoleh lingkungan hidup yang bersih dan sehat; (i) Hak untuk mendapatan barang sesuai dengan nilai tukar yang diberikannya, dan (j) Hak untuk mendapatkan upaya penyelesaian hukum yang patut.

Dari kesepuluh hak konsumen tersebut, ada dua hak yang sangat bersinggungan dengan permasalahan dalam pembahasan ini. Kedua hak itu adalah :

a. Hak untuk memperoleh ganti rugi kerugian, ganti rugi merupakan hal yang wajib dipenuhi, jika salah satu pihak mengalami kerugain materil akibat dari perbuatan melawan hukum dan ataupun wanprestasi dari pihak lainnya. Yang mana seharusnya, kewajiban untuk mengganti kerugian tersebut muncul secara otomatis. Namun kesadaran untuk mengganti rugi tersebut baru akan muncul secara terpaksa, jika pihak yang dirugikan tersebut melakukan penuntutan atau telah jatuhnya putusan yang mengharuskan adanya ganti rugi.

b. Hak untuk mendapatkan upaya penyelesain hukum yang patut, sebagai seorang nasabah atau konsumen yang bila mana kepentingannya dilanggar, tentu saja selain mekanisme ganti rugi, juga nasabah mutlak membutuhkan upaya penyelesaian hukum yang patut. Seperti diuraikan sebelumnya bahwa kebanyakan ganti rugi hanya dilakukan secara terpaksa, dikarenakan akibat jatuhnya putusan yang mengharuskan ganti rugi dilakukan.

Seringkali nasabah memperoleh penyelesaian yang lumayan berbelit-belit. Sehingga tidak menyelesaikan masalah, tapi malah akan menambah masalah. Kalaupun pihak bank pada saat itu bersedia melakukan penyelesaian secara kekeluargaan, justru kadang penggantian yang ditawarkan sangatlah jauh dari memuaskan. Dengan demikian, mekanisme hukumpun menjadi salah satu solusi yang layak untuk ditempuh, yakni berupa ganti kerugian, sehingga yang diharapkan dapat diterima secara pantas. Dilihat dari fungsinya, bank mempunyai fungsi berupa penyaluran dan pengerahan dana dengan hubungan hukum antara bank dengan nasabah debitur dan nasabah penyimpan dana. Dalam hal penggunaan Automatic Teller Machine misalnya, setiap perjanjian yang dibuat nasabah dan bank, tidaklah boleh memuat klausul baku yang menyatakan pengalihan tanggung jawab bank sepenuhnya kepada nasabah dan memuat pernyataan tunduknya nasabah pada peraturan yang berupa aturan baru, lanjutan, dan tambahan, ataupun pengubahan lebih lanjut yang dibuat secara sepihak oleh bank. 
Dalam prakteknya, klausula-klausula baku yang menyatakan pengalihan tanggung jawab sepenuhnya kepada nasabah tentu tidak memenuhi rasa keadilan dilihat dari sudut manapun. Dimana klausula baku menjadi standar dalam setiap perjanjian dengan bank, termasuk perjanjian penggunaan Automatic Teller Machine. Pada undang-undang perbankan tidak memberikan perlindungan hukum secara spesifik terhadap nasabahnya terutama pengaturan mengenai penggunaan Automatic Teller Machine. Jika nasabah bank pengguna kartu Automatic Teller Machine mengalami kerugian yang disebabkan bukan karena kesalahan dari nasabah, maka pihak bank wajib memberi ganti rugi sebagaimana yang diatur pada Pasal 10 Peraturan Bank Indonesia Nomor: 16/1/PBI/2014 tentang Perlindungan Konsumen Jasa Pembayaran, yang menyatakan bahwa Penyelenggara wajib bertanggung jawab kepada konsumen atas kerugian yang timbul akibat kesalahan pengurus dan pegawai penyelenggara.

Dari ketentuan tersebut, dapat diketahui bahwa penyelenggara dalam hal ini pihak bank wajib bertanggung jawab kepada nasabah untuk ganti rugi atas kerugian yang bukan menjadi kesalahan nasabah, tapi atas kelalaian dari pihak bank itu sendiri selaku penyelenggara. Dalam penyelesaian pengaduan nasabah, bank mengupayakan dalam waktu satu hari, yakni saat adanya pelaporan dari nasabah ke Customer Service, selanjutnya dari Customer Service kemudian melakukan penanganan pengaduan dengan meminta nasabah mengisi form pengaduan disertai dengan melampirkan kartu identitas dan buku tabungan, kemudian oleh Customer Service melakukan pendataan identitas dan isi pengaduan nasabah, untuk proses permasalahan nasabah diminta menunggu dalam rentan waktu empat belas hari kerja.

Lebih lanjut bahwa pernah terjadi beberapa kasus, seorang nasabah pernah menerima telpon dari seseorang oknum yang mengaku dari pihak bank, yang menginformasikan bahwa nasabah ini berdasarkan hasil undian memenangkan hadiah berupa alat-alat elektronik yang bisa dipilih secara lansung hadiahnya di kantor cabang terdekat. Selanjutnya nasabah diminta untuk mencocokkan identitas sesuai dengan data KTP, kemudian nomor rekeneing yang disusul dengan masuknya pesan singkat dari bank yang mengirimkan kode One Time Password kepada nasabah. Nasabah kemudian diminta untuk menyebutkan kode yang masuk via pesan singkat dari bank untuk validasi data nasabah, agar selanjutnya dikirimkan kode. Kode tersebut yang kemudian dibawah ke bank pada saat pengambilan hadiah.

Selain kasus tersebut juga pernah terjadi kasus yang hampir sama yakni ada beberapa nasabah yang pernah menerima pesan singakat bahkan menerima telpon dari seseorang yang juga mengaku dari pihak bank, yang mengatakan bahwa si nasabah mendapatkan kupon undian yang selanjutnya dapat digunakan untuk mengambil hadiah. Nasabah kemudian diminta untuk 
mencocokkan identitas sesuai dengan data Kartu Tanda Penduduk, selanjutnya nomor rekening dan terakhir diminta menyebutkan atau mengirimkan via pesan singkat nomor kartu Automatic Teller Machine untuk keperluan validasi data nasabah ke nomor sipenelpon.

Berdasarkan hasil penelitian bahwa pihak bank sama sekali tidak pernah melakukan pengumuman yang pelaksanaannya dan pemberitahuannya melalui pesan singkat, lewat media sosial Whatsapp ataupun via telpon dengan nomor pribadi. Kemudian adanya himbauanhimbauan kepada masyarakat khususnya nasabah bank agar jangan sama sekali memberikan info tentang nomor kartu Automatic Teller Machine, Personal Identification Number ataupun kode One Time Password kepada siapapun, bahkan kepada petugas sekalipun karena merupakan rahasia nasabah. Dikhawatirkan informasi pribadi yang diberikan kemudian dapat disalahgunakan sehingga terjadi hal-hal yang tidak diinginkan seperti skimming ataupun phising terhadap data nasabah yang bisa berakibat hilangnya dana nasabah tanpa sepengetahuan nasabah. Masyarakat khususnya nasabah Bank yang menjadi korban dihimbau untuk datang ke kantor-kantor cabang untuk melakukan pengaduan. Pengaduan nasabah kemudian akan diproses lebih lanjut.

\section{Perlindungan Dan Tanggung Jawab Hukum Perbankan Terhadap Nasabah}

Kejahatan yang menggunakan media perbankan dapat dikelompokkan menjadi dua jenis yakni:

a. Tindak pidana perbankan : yaitu kejahatan yang diatur dalam undang-undang perbankan (Undang-undang Bank Indonesia, Undang-undang Otoritas Jasa Keuangan, Undang-undang Perbankan, Peraturan Bank Indonesia, dan Peraturan Otoritas Jasa Keaungan), seperti Tindak Pidana Rahasia Bank.

b. Tindak pidana di bidang perbankan : yaitu kejahatan yang menyangkut bank tetapi tidak diatur dalam Undang-undang Perbankan, misalkan Tindak Pidana Pencucian Uang.(Murwadji, 2016)

Dari dua jenis tindak pidana medianya ialah perbankan. Olehnya itu, bank dalam hal ini sebagai korporasi pastinya terlibat sebagai media. Dalam Undang-undang Nomor 10 tahun 1998 tentang Perbankan, setelah dianalisa tidak ada ketentuan secara khusus yang mengatur permasalahan perlindungan hukum kepada konsumen perbankan. Undang undang ini hanya menyebutkan secara jelas bahwa pengawasan dan pembinaan perbankan dilakukan oleh Bank Indonesia.(Disemadi \& Prananingtyas, 2019)

Sifat dasar nasabah umumnya kurang mempunyai sifat kritis dalam rangka mempertahankan hak-haknya. Salah satu persoalan yang sering muncul dan mendapat 
persoalan dalam pemenuhan hak-haknya. Pemerintah dan penegak hukum yang kurang serius dalam memberikan perlindungan terhadap nasabah serta keterbatasan sumber daya manusia yang kurang memadai turut andil dalam permasalahan terpenuhinya hak-hak konsumen.(Palilati, 2017)

Pada Undang-undang Perlindungan Konsumen menyatakan bahwa yang dimaksud dalam perlindungan konsumen adalah segala upaya yang dapat menjamin kepastian hukum untuk memberikan perlindungan terhadap konsumen pengguna jasa perbankan. Hukum perlindungan konsumen dibutuhkan jika kondisi para pihak yang mengadakan kerjasama ataupun perikatan mengalami masalah antara penyelenggara yakni bank dan konsumen sebagai nasabah. Karena pada keyataannya dalam keseharian masyarakat yang berkebutuhan besar tersebut sangat lemah dibandingan dengan penyedia layanan.

Hukum perlindungan komsumen merupakan keseluruhan dari asas dan kaidah-kaidah hukum yang mengatur dan melindungi konsumen dalam hubungan dan masalah yang terjadi dengan penyedia jasa. Ketidakseimbangan yang terjadi ini lambat laun akan berpengaruh pada kepentingan-kepentingan pihak lain, karena konsumen merupakan pelaku ekonomi yang sangat penting dalam kegiatan ekonomi. Jika salah satu pelaku ekonomi tidak menjalankan kegiatannya atau menundanya maka prestasi kegiatan pelaku lainnya menjadi terbengkalai.(Nasution, 2002)

Perlindungan terhadap konsumen pada umumnya dan perlindungan nasabah bank pada khususnya, merupakan topik yang menarik karena pada kenyataannya, konsumen atau nasabah bank seringkali menjadi pihak yang dirugikan. Hubungan antara bank dengan nasabah sebagai konsumen merupakan hubungan yang timpang karena di satu sisi bank mempunyai Bargaining Power yang lebih kuat sehingga nasabah berada pada posisi Take It Or Leave It. Dengan hubungan yang tidak seimbang ini, perlindungan terhadap nasabah sebagai konsumen bank menjadi sangat penting.(Sutrisno Fernando Ngiu, 2015) Nasabah sebagai pengguna fasilitas kartu Automatic Teller Machine sebagaimana yang diatur dalam Pasal 1 ayat 2 Undang-undang Nomor 8 Tahun 1998 Tentang Perlindungan Konsumen. Pengertian konsumen secara harfiah ialah Seorang yang membeli barang atau mempergunakannya sebagai salah satu jasa. Sekaitan dengan perlindungan hukum terhadap nasabah ini, dalam sistem perbankan Indonesia, mengenai perlindungan terhadap nasabah penyimpan dana, dapat dilakukan melalui dua cara, yaitu: 
a. Perlindungan secara implisit, yaitu perlindungan yang dihasilkan oleh pengawasan dan pembinaan bank yang efektif, yang dapat menghindarkan terjadinya kebangkrutan bank. Dan

b. Perlindungan secara eksplisit, yaitu perlindungan melalui pembentukan suatu lembaga yang menjamin simpanan masyarakat, sehingga apabila bank mengalami kegagalan, lembaga tersebut yang akan mengganti dana masyarakat yang disimpan pada bank gagal tersebut melalui pembentukan lembaga yang menjamin simpanan masyarakat, sebagaimana yang diatur dalam Keputusan Presiden Nomor 26 Tahun 1998 tentang Jaminan Terhadap Kewajiban Bank Umum.(Tengku Andrias Prayudha, 2015)

\section{Perlindungan Hukum Bagi Nasabah Menurut Kontrak Penerbitan Kartu Automatic Teller Machine}

Konsumen selaku pengguna layanan barang atau jasa yang ditawarkan pihak bank dalam memperkenalkan produk bank. Pihak perbankan menawarkan produknya kepada para calon nasabah ataupun nasabahnya, agar nasabah dapat tertarik dan kemudian mempercayakan bank dengan memberikan sejumlah uang yang dapat disimpan dalam bank tersebut. Produkproduk tersebut dapat berupa Electronic Banking, deposito, tabungan, kartu Automatic Teller Machine, kartu kredit, dan lain-lain.

Salah satu kegiatan sistem pembayaran yang saat ini telah berkembang dengan pesat yakni Alat Pembayaran dengan Menggunakan Kartu (APMK) atau disebut pula dengan kartu plastik. Kartu Automatic Teller Machine merupakan Alat Pembayar Menggunakan Kartu (APMK). Kartu Automatic Teller Machine merupakan komponen dari mesin yang digunakan bank untuk melayani transaksi-transaksi keuangan, berupa pengecekan saldo, transfer, penyetoran tunai, dan transaksi keuangan lainnya secara elektronik. Automatic Teller Machine dapat juga dikatakan sebagai mesin kasir otomatis. Kontrak penerbitan kartu Automatic Teller Machine tidak secara rinci yang mengatakan bahwa nasabah memperoleh perlindungan hukum atas penggunaan transaksi kartu Automatic Teller Machine yang bermasalah. Artinya bahwa jika nasabah mengalami masalah dalam melakukan transaksi kartu Automatic Teller Machine, nasabah bisa berpedoman pada Undang-undang Perbankan dan Undang-undang Perlindungan Konsumen.

\section{Perlindungan Hukum Bagi Nasabah Menurut Undang-Undang Perbankan.}

Bank dalam menjalankan tugasnya berdasar pada kepercayaan masyarakat. Masyarakat sebagai nasabah percaya bahwa uang yang disimpan di bank selalu aman. Sebaliknya, bank 
yang diberi kepercayaan masyarakat perlu selalu menjaga kesehatan dirinya agar kepercayaan itu terus terpelihara. Untuk itu, diperlukan adanya pembinaan dan pengawasan terhadap bank. (Supramono, 1997)

Kebanyakan dari nasabah pengguna kartu Automatic Teller Machine, telah banyak yang mengalami masalah-masalah seperti uang yang tidak keluar pada saat penarikan, kartu Automatic Teller Machine tertelan, skimming, Phising dan lain-lain. Pada Undang-undang Perbankan bisa dikatakan bahwa belum memuat secara terperinci mengenai ketentuan perlindungan hukum bagi nasabah bank. Dimana yang diatur dalam Undang-undang Perbankan disebutkan bahwa Untuk kepentingan nasabah, bank menyediakan informasi mengenai kemungkinan timbulnya resiko kerugian bagi transaksi nasabah yang dilakukan melalui bank. Dari Pasal tersebut bisa dilihat bahwa hanya sedikit penjelasan mengenai perlindungan hukum terhadap nasabah bank. Dimana jika kita lihat dalam penjelasan Pasal tersebut tidak dapat diberikan penjelasan dan pengertian secara menyeluruh tentang apa dan bagaimanakah kepentingan nasabah yang tidak boleh dirugikan.

Pada Surat Edaran Nomor 14/17/DASP/2012 tanggal 7 Juni 2012 Perihal Perubahan atas Surat Edaran Bank Indonesia Nomor 11 / 10 / DASP / 2009 tanggal 13 April 2009 Perihal Penyelenggaraan Kegiatan Alat Pembayaran dengan Menggunakan Kartu, penerbit wajib memberikan informasi tertulis kepada pemegang kartu, sekurang-kurangnya meliputi :

a. Prosedur dan tata cara pengguna kartu, fasilitas yang melekat pada kartu, dan resiko yang mungkin timbul dari penggunaan kartu tersebut.

b. Hak dan kewajiban pemegang kartu, sekurang-kurangnya meliputi:

a) Hal-hal penting yang harus diperhatikan oleh pemegang kartu dalam penggunaan kartunya, termasuk segala konsekuensi yang mungkin saja timbul dari penggunaan kartu, misalnya tidak memberikan Personal Identification Number kepada orang lain dan berhati-hati saat melakukan transaksi melalui mesin Automatic Teller Machine.

b) Hak dan tanggung jawab pemegang kartu dalam hal terjadi berbagai hal yang mengakibatkan kerugikan bagi pemegang kartu dan atau penerbit, baik yang disebabkan karena adanya pemalsuan kartu, kegagalan system penerbit, atau sebab yang lainnya.

c) Jenis dan besarnya biaya yang dikenakan,dan

d) Tata cara dan konsekuensi apabila pemegang kartu tidak lagi berkeinginan menjadi pemegang kartu. 
c. Tata cara pengajuan pengaduan yang berkaitan dengan penggunaan kartu dan perkiraan waktu penanganan pengaduan tersebut.

Dalam praktek perbankan, suatu perjanjian antara bank dan pihak nasabah belum bisa dibuat sebagaimana dengan mestinya, artinya hanya untuk melindungi kepentingan bank, tetapi tidak memberikan perlindungan yang cukup memadai terhadap kepentingan nasabah. Berdasarkan permasalahan yang ada, masalah-masalah dapat dibagi menjadi dua kelompok kasus permasalahan Automatic Teller Machine yaitu kasus permasalahan secara yuridis dan kasus permasalahan secara teknis. Kasus permasalahan secara yuridis yang dimaksud disini adalah kasus yang diluar dari kehendak nasabah sehingga berakibat nasabah mengalami kerugian baik secara materil dan imateril.

\section{Perlindungan Hukum Bagi Nasabah Berdasarkan Undang-undang Perlindungan Konsumen.}

Perlindungan konsumen ialah upaya untuk menjamin adanya kepastian hukum dan memberi perlindungan kepada konsumen. Olehnya itu, perlu diketahui terlebih dahulu tentang pihak yang disebut dengan konsumen. Pengertian konsumen dapat dibagi menjadi tiga bagian, yaitu:

a. Konsumen dalam arti yang umum yakni pemakai, pengguna atau pemanfaat barang dan jasa untuk tujuan tertentu.

b. Konsumen antara yakni pemakai, pengguna atau pemanfaat barang dan jasa untuk diproduksi menjadi barangdan jasa lain atau untuk diperdagangkan dengan tujuan komersial.

c. Konsumen akhir yakni pemakai, pengguna atau pemanfaat barang dan jasa untuk memenuhi kebutuhan diri sendiri, keluarga ataupun rumah tangganya dan tidak untuk diperdagangkan kembali. (Meilianasari, 2013)

Hubungan yang terjalin antara nasabah selaku konsumen dengan bank didasarkan pada prinsip kepercayaan, akan tetapi pada praktiknya sangat rentan terjadi atau timbul sengketa di antara kedua pihak. Perselisihan atau sengketa tersebut biasanya disebabkan dimana salah satu pihak tidak menjalankan kesepakatan yang telah dibuat ataupun adanya salah satu pihak yang melakukan wanprestasi, sehingga merugikan pihak lainnya. Dari berbagai pengalaman yang ada, timbulnya konflik tersebut terutama disebabkan oleh empat hal di bawah ini :

a. Informasi yang kurang memadai mengenai karakteristik produk atau jasa yang ditawarkan oleh bank.

b. Pemahaman nasabah terhadap aktivitas dan produk atau jasa yang masih kurang. 
c. Ketimpangan hubungan antara nasabah dengan bank, khususnya bagi nasabah peminjam dana, dan

d. Tidak adanya saluran yang memadai untuk menfasilitasi penyelesaian awal friksi yang terjadi antara nasabah dengan bank.

Melihat dari empat hal tersebut, maka bisa dilihat bahwa begitu mudahnya terjadi perselisihan atau sengketa antara nasabah dengan bank. Olehnya itu harus ada perlindungan nasabah, karena hal tersebut sangat berpengaruh bagi nasabah, dengan demikian menjadi tantangan yang besar bagi perbankan dan Bank Indonesia untuk menciptakan standar yang jelas dalam memberikan perlindungan terhadap nasabah.(Muhammad Audi, 2019).

Undang-undang Perlindungan Konsumen diharapkan dapat menjadi dasar hukum bagi nasabah yang merasa dirugikan dan menuntut haknya. Jika kemudian terjadi masalah dalam penggunaan kartu Automatic Teller Machine yang mengakibatkan kerugian yang bukan karena kesalahan dari nasabah maka pihak bank wajib mengganti kerugian. sebagaimana diatur dalam Undang-undang Perlindungan Konsumen pada Pasal 7 huruf F, huruf G. Dan pada Pasal 19 ayat (1). Sedangkan jika dilihat lagi pada Pasal 45 Ayat (1) jelas bahwa konsumen yang dirugikan dapat menggugat pelaku usaha melalui peradilan umum. Kemudian Ayat (2) juga mengaskan bahwa konsumen dalam hal ini sebagai nasabah dapat menempuh jalur hukum melalui pengadilan ataupun diluar pengadilan, berdasar pada pilihan sukarela para pihak yang bersengketa.

Masalah masyarakat, umumnya karena masyarakat belum mengetahui dan memahami tentang tanggung jawab yang diatur dalam Undang-undang Nomor 8 Tahun 1999 tentang Perlindungan Konsumen. Masyarakat selaku konsumen atau nasabah juga pada umumnya belum mengetahui hak dan kewajibannya sebagai nasabah apabila terjadi masalah dalam penggunaan fasilitas kartu Automatic Teller Machine. Kurangnya sosialisasi terhadap aturanaturan hukum pada nasabah sehingga mereka tidak memahami perlindungan hukum apabila masyarakat mengalami kerugian terutama masalah penggunaan kartu Automatic Teller Machine.

\section{SIMPULAN}

Berdasarkan penelitian dan pembahasan yang telah di uraikan sebelumnya, maka ditarik kesimpulan bahwa :

Tanggung jawab bank terhadap kerugian nasabah, berdasarkan kontrak penerbitan kartu Automatic Teller Machine didalamnya tidak terdapat pengalihan tanggung jawab secara keseluruhan dari bank ke nasabah, jika nasabah pengguna kartu Automatic Teller Machine 
kemudian mengalami kerugian yang bukan disebabkan karena kesalahan nasabah, maka bank tentunya wajib untuk memberi ganti rugi. Dan Untuk upaya hukum yang dapat dilakukan oleh nasabah dalam memperoleh hak-haknya jika terjadi kerugian dalam penggunaan fasilitas kartu Automatic Teller Machine maka dipersilahkan untuk melakukan pengaduan secara tertulis kepada kantor cabang bank. Pengaduan pemegang kartu yang disampaikan kepada bank setelah tiga bulan atau lebih sejak tanggal transaksi tersebut tidak akan dilayani.

\section{DAFTAR PUSTAKA}

\section{Buku dan Jurnal}

Disemadi, H. S., \& Prananingtyas, P. (2019). Perlindungan Hukum Terhadap Nasabah Perbankan Pengguna Crm (Cash Recycling Machine). Jurnal Magister Hukum Udayana (Udayana Master Law Journal), 8(3), 286. Https://Doi.Org/10.24843/Jmhu.2019.V08.I03.P07

Fuady, M. (2001). Hukum Perbankan Modern. Pt. Citra Aditya Bakti.

Meilianasari, Y. D. (2013). Analisis Kepercayaan Nasabah Pengguna Atm. Manajemen Bisnis, 2(1). Https://Doi.Org/10.22219/Jmb.V2i1.1482

Muhammad Audi. (2019). Mediasi Perbankan Dalam Penyelesaian Sengketa Antara Nasabah Dan Bank. Supremasi Jurnal Hukum, 2, 2.

Murwadji, T. (2016). Etika Bisnis Sebagai Dasar "Pertanggungjawaban Sosial Dan Lingkungan" Perbankan. Jurnal Hukum Positum, 1(1), 1. Https://Doi.Org/10.35706/Positum.V1i1.520

Nasution, A. Z. (2002). Hukum Perlindungan Konsumen. Daya Widya.

Nawi, S. (2017). Penelitian Hukum Normatif Versus Penelitian Hukum Empiris (5th Ed.). Pt.Umitoha Ukhuwah Grafika.

Palilati, R. M. (2017). Perlindungan Hukum Konsumen Perbankan Oleh Otoritas Jasa Keuangan. Jurnal Ius Kajian Hukum Dan Keadilan, 5(1), 49. Https://Doi.Org/10.29303/Ius.V5i1.414

Said, A. (2017). Perlindungan Hukum Bagi Nasabah Yang Didaftarhitamkan Akibat Kesalahan Sistem Perbankan Menurut Uu No. 10 Tahun 1998 Tentang Perbankan. Lex Crimen, 6(3).

Supramono, G. (1997). Tindak Pidana Korupsi Di Bidang Perkreditan. Alumni. 
Sutrisno Fernando Ngiu. (2015). Perlindungan Hukum Terhadap Nasabah Bank Sebagai Subjek Hukum Menurut Undang -Undang Nomor 10 Tahun 1998 Tentang Perbankan. Lex Privatum, 3(1), 241.

Tarigan, H. A. A. B., \& Paulus, D. H. (2019). Perlindungan Hukum Terhadap Nasabah Atas Penyelenggaraan Layanan Perbankan Digital. Jurnal Pembangunan Hukum Indonesia, 1(3), 294-307. Https://Doi.Org/10.14710/Jphi.V1i3.294307

Tengku Andrias Prayudha. (2015). Tinjauan Yuridis Perlindungan Hukum Nasabah Perbankan Berdasarkan Undang-Undang Nomor 21 Tahun 2011 Tentang Otoritas Jasa Keuangan. Jom Fakultas Hukum, 2, 5.

\section{Peraturan perundang-undang}

Peraturan Bank Indonesia Nomor: 16 /1/PBI/2014 tentang Perlindungan Konsumen Jasa Pembayaran

Undang-undang Nomor 10 Tahun 1998 tentang Perbankan

Undang-undang Nomor 8 Tahun 1999 Tentang Perlindungan Konsumen Penjelasan atas Undang-undang No 8 Tahun 1999 tentang Perlindungan Konsumen

Undang-undang Nomor 19 Tahun 2016 Tentang Perubahan Atas Undang-undang No 11 Tahun 2008 Tentang Informasi Dan Transaksi Elektronik

Surat Edaran Bank Indonesia Nomor 10/13/DPNP/ 2008 dan Peraturan Bank Indonesia Nomor 10 / 10 / 2008 Tentang Pengaduan Nasabah.

Surat Edaran Nomor 14/17/DASP/2012 7 Juni 2012 Perihal Perubahan atas Surat Edaran Bank Indonesia Nomor 11/10/DASP/2009 13 April 2009 Perihal Penyelenggaraan Kegiatan Alat Pembayaran dengan Menggunakan Kartu 